\title{
PENERAPAN ASSERTIVENESS TRAINING DAN TERAPI KELOMPOK SUPORTIF MENGGUNAKAN TEORI STRES ADAPTASI STUART DAN TEORI ADAPTASI ROY
}

\author{
Neng Esti Winahayu ${ }^{1 *}$, Achir Yani Syuhaimie Hamid ${ }^{2}$, Novy Helena Chatarina Daulima ${ }^{2}$ \\ ${ }^{1}$ RS Jiwa Dr. Soeharto Heerdjan Jakarta \\ ${ }^{2}$ Departemen Keperawatan Jiwa Fakultas Ilmu Keperawatan Universitas Indonesia \\ *estiwinahayu@yahoo.co.id
}

\begin{abstract}
ABSTRAK
Perilaku kekerasan merupakan perilaku atau tindakan seseorang ketika tidak mampu mengatasi stressor yang dialaminya, ditunjukkan dengan perilaku aktual berupa kekerasan baik pada diri sendiri, orang lain, maupun lingkungan baik secara verbal maupun non verbal (Stuart, 2013). Tujuan penulisan karya ilmiah akhir ini adalah menggambarkan penerapan assertiveness training dan terapi kelompok suportif menggunakan Teori Stres Adaptasi Stuart dan Adaptasi Roy pada klien resiko perilaku kekerasan di Rumah Sakit Marzoeki Mahdi Bogor. Intervensi keperawatan yang dilakukan adalah assertiveness training pada 6 klien dan kombinasi terapi assertiveness training dan terapi kelompok suportif pada 12 orang klien. Pelaksanaan assertiveness training dan terapi kelompok suportif dapat menurunkan tanda dan gejala perilaku kekerasan pada aspek kogitif, afektif, fisiologis, perilaku, dan sosial serta meningkatkan kemampuan adaptif dalam menghadapi peristiwa yang menimbulkan perilaku kekerasan.
\end{abstract}

Kata kunci: risiko perilaku kekerasan, assertiveness training, terapi kelompok suportif, teori stres adaptasi stuart, adaptasi roy

\section{APPLICATION OF ASSERTIVENESS TRAINING AND SUPPORTIVE GROUP THERAPY USING THEORY OF STRESS ADAPTATION STUART AND THEORY OF ROY ADAPTATION APPROACH}

\begin{abstract}
Violent behavior occurs when a person is not capable of responding to stressors. This behavior can be manifested by hurting oneself, others, or environment verbally or non verbally (Stuart, 2013). The purpose of this scientific paper was to report the application of assertiveness training and supportive group therapy utilizing the Stuart's Stress-Adaptation Theory and Roy's Adaptation Theory towards the clients with potential risk violent behavior who were hospitalized at Marzoeki Mahdi Hospital in Bogor. Assertiveness training was conducted to six clients and combination of assertiveness training and supportive group therapy to twelve clients. The result of assertiveness training and supportive group therapy depicted that there were decreased signs and symptoms of violent behaviors at all aspects of cognitive, affective, physiological, behavior, and social as well as improvement of ability of clients to be more adaptive in responding to the any stressful situation that can stimuli violent behaviors. It is recommended that assertiveness training and supportive group therapy can be used as a standard of mental health-psychiatric nursing specialized therapy.
\end{abstract}

Keywords: violent risk behavior, assertiveness training, supportive group therapy, stuart's stressadaptation theory and roy's adaptation theory

\section{PENDAHULUAN}

Undang-Undang Nomor 36 tahun 2009 tentang kesehatan, menjelaskan bahwa kesehatan adalah suatu keadaan sehat, baik secara fisik, mental, spiritual maupun sosial yang memungkinkan setiap orang hidup produktif secara sosial dan ekonomi. Sedangkan kesehatan jiwa adalah adalah suatu kondisi sehat emosional, psikologis, dan sosial yang terlihat dari hubungan interpersonal yang memuaskan, perilaku dan koping yang efektif, konsep diri yang positif, dan kestabilan emosional (Videbeck, 2008). Kesehatanjiwa merupakan bagian dari kesehatan.

Berdasarkan hasil riset kesehatan dasar (Riskesdas) tahun 2007 ditemukan $0.46 \%$ penduduk Indonesia mengalami gangguan 
jiwa berat (Depkes RI, 2008). Prevalensi tertinggi untuk gangguan jiwa berat di Provinsi DKI Jakarta (2.03\%), Jawa Barat $(0.20 \%)$ dan kota Bogor $(0.40 \%)$. Disimpulkan bahwa prevalensi gangguan jiwa khususnya di kota Bogor $(0.40 \%)$ melebihi prevalensi di dunia $(0.30 \%)$.

Gangguan jiwa yang sering terjadi adalah skizofrenia. Skizofrenia adalah sekumpulan sindrom klinik yang ditandai dengan adanya perubahan secara kognitif, emosi, persepsi, dan aspek lain dari perilaku (Kaplan \& Sadock, 2007). Skizophrenia ditandai dengan adanya gejala positif dan negatif. Perilaku kekerasan merupakan salah satu gejala positif. Perilaku kekerasan merupakan salah satu respons maladaptif ketika seseorang sedang marah sebagai ungkapan perasaan jengkel yang timbul akibat respons terhadap kebutuhan yang tidak terpenuhi yang dirasakan sebagai ancaman (Stuart, 2013). perilaku kekerasan perlu dukungan dari keluarga maupun perawat, sehingga tidak membahayakan diri sendiri maupun orang lain.

Intervensi untuk klien perilaku kekerasan dapat berupa tindakan generalis maupun tindakan spesialis. Tindakan keperawatan spesialis untuk mengatasi perilaku kekerasan pada klien gangguan jiwa adalah terapi assertiveness training (AT) dan terapi kelompok suportif. Peningkatan kesadaran diri, edukasi klien, dan assertiveness training (AT) merupakan cara untuk mencegah terjadinya perilaku kekerasan yang merupakan bagian dari strategi preventif (Stuart, 2013)

Hasil penelitian ditemukan bahwa bahwa terapi generalis dan assertiveness training dapat menurunkan kejadian perilaku kekerasan pada 36 orang klien (50\%) dari 72 klien dengan diagnosa risiko perilaku kekerasan yang dirawat di RSUD Banyumas (Wahyuningsih, Keliat, \& Hastono, 2009). Penelitian pada 30 orang klien dengan risiko perilaku kekerasan menunjukkan bahwa terjadi penurunan tanda gejala perilaku kekerasan dan peningkatan kemampuan setelah mendapat assertiveness training (Alini, Keliat, \& Wardani, 2010). Penelitian lain menunjukkan bahwa kemampuan anak mengelola emosi meningkat secara bermakna $(p$-value $<0,05)$ yang 30 orang tuanya yang mengikuti latihan asertif (Gowi, Hamid, \& Nuraini, 2011). Hasil penelitian lain menunjukkan bahwa terjadi penurunan kekerasan dalam rumah tangga sebesar 29,6\% setelah diberikan assertiveness training (Aini, Keliat, \& Nuraini, 2011) Dapat disimpulkan bahwa terapi asertif efektif dilakukan pada klien yang mengalami risiko perilaku kekerasan.

Terapi kelompok suportif bertujuan memberikan dukungan terhadap anggota kelompok sehingga mampu menyelesaikan krisis yang dihadapinya, meningkatkan kekuatan, keterampilan koping, dan menggunakan sumber-sumber koping (Mohr, 2006). Penelitian terhadap 42 klien resiko perilaku kekerasan di RS Amino Gondohutomo Semarang, menunjukkan bahwa ada perubahan bermakna pada klien sebelum dan sesudah dilakukan terapi kelompok suportif (Hidayati, Mustikasari, \& Pujasari, 2011)

\section{METODE}

Karya ilmiah tentang penerapan assertiveness training dan terapi kelompok suportif pada klien risiko perilaku kekerasan menggunakan pendekatan Teori Stress Adaptasi Stuart dan Adaptasi Roy. Karya ilmiah bertujuan untuk mengetahui perbedaan hasil penerapan assertiveness training pada 6 klien risiko perilaku kekerasan dan penerapan kombinasi assertiveness training dan terapi kelompok suportif pada 12 klien risiko perilaku kekerasan.

Karya ilmiah ini menggunakan metode penerapan assertiveness training dan kombinasi assertiveness training dan terapi kelompok suportif. Sampel klien adalah 18 orang yang memenuhi kriteia yaitu klien dengan risiko perilaku kekerasan yang dirawat di RSMM Bogor, mampu membaca dan menulis, kooperatif. Sampel klien dibagi menjadi 2 kelompok. Kelompok yang dilakukan satu terapi assertiveness training dilakukan pada 6 klien, sedangkan kombinasi terapi yaitu assertiveness training dan terapi kelompok suportif dilakukan pada 12 orang.

\section{HASIL}

Klien dengan risiko perilaku kekerasan mayoritas laki-laki, berusia dewasa 25-56 (55.56\%) tahun, pendidikan sebagian besar SMP (33.33\%) dan SMA (33.33\%), tidak bekerja $(88.89 \%)$, status perkawinan belum menikah (44.44\%), lama sakit rata-rata 5 tahun, dan frekuensi dirawat di RS rata-rata 2 kali. 
Faktor presipitasi (stimulus fokal) adalah perilaku yang menjadi alasan klien dirawat di RS yaitu marah-marah. Faktor predisposisi (stimulus kontekstual) adalah gangguan sebelumnya $(83.33 \%)$, kepribadian tertutup $(66.67 \%)$, tidak bekerja $(83.33 \%)$. Stimulus residual adalah adanya stigma bahwa gangguan jiwa adalah hal yang negatif (100\%).

Tanda gejala klien risiko perilaku kekerasan sebelum dilakukan tindakan keperawatan paling banyak adalah respons kognitif tidak mampu mengungkapkan masalah (88.89\%), respons afektif sebagian besar adalah afek labil, kecewa/kesal, dan mudah tersinggung (masing-masing 100\%). Respon fisiologis sebagian besar adalah kewaspadaan meningkat (100\%). Respon perilaku sebagian besar adalah mondar-mandir (100\%). Respon sosial sebagian besar adalah menarik diri $(55.56 \%)$.

Sumber koping klien adalah klien sudah mampu mengontrol emosi dengan spiritual $(83.33 \%)$, caregiver paling banyak adalah orang tua kandung (50\%), tidak tahu cara merawat klien (94.44\%). Dukungan kelompok tidak ada (100\%) dan tidak ada kader kesehatan jiwa (100\%). Pembayaran yang digunakan paling banyak adalah BPJS (94.44\%), sebagian besar tidak mempunyai pekerjaan atau penghasilan sendiri $(88.89 \%)$ dan tidak mampu membiayai hidup (88.89\%), jangkauan ke fasilitas kesehatan sebagian besar adalah dekat (77.78\%). Semua klien yakin akan sembuh, percaya dengan petugas kesehatan, dan fasilitas kesehatan yang digunakan saat ini. Mekanise koping adalah denial (94.44\%).

Assertiveness training dilakukan 3-4 kali pertemuan. Terapi kelompok suportif dilakukan 4 kali pertemuan sesuai dengan kontrak klien. Sebelum dilakukan terapi spesialis, klien dilakukan tindakan keperawatan generalis. Kemampuan klien setelah diberikan assertiveness training mengalami peningkatan $100 \%$ pada sesi 1 sampai 4, sedangkan sesi 5 hanya 66.67. Sesi 5 ada 2 klien yang tidak mampu mempertahankan bagaimana bersikap asertif sesuai dengan yang sudah didiskusikan dan sudah dilatih. Tanda dan gejala risiko perilaku kekerasan mengalami penurunan. Rata-rata penurunan tanda gejala kognitif $60.01 \%$, afektif $69.44 \%$, fisiologis 35.71, perilaku $19.04 \%$, dan sosial $19.99 \%$.
Kemampuan klien setelah assertiveness training dan terapi kelompok suportif mengalami peningkatan. Kemampuan dalam assertiveness training masing-masing sesi dari sesi 1 sampai 5 mengalami peningkatan $100 \%$. Kemampuan dalam terapi kelompok suportif mengalami peningkatan rata-rata $83.33 \%$. Tanda dan gejala perilaku kekerasan sudah tidak dimiliki klien.

Perubahan tanda dan gejala perilaku kekerasan, pada 6 klien yang mendapatkan assertiveness training sebesar $40.83 \%$. Klien yang diberikan assertiveness training dan terapi kelompok suportif (12 orang) ditemukan penurunan tanda dan gejala perilaku kekerasan sebesar $54.53 \%$. Penurunan tanda dan gejala perilaku kekerasan lebih besar pada klien yang diberikan assertiveness training dan terapi kelompok suportif daripada yang hanya diberikan assertiveness training. Perubahan kemampuan klien resiko perilaku kekerasan yang hanya diberikan assertive training sebesar 93.33\%. Sedangkan klien yang mendapatkan assertiveness training dan terapi kelompok suportif, kemampuan asertif meningkat $100 \%$ dan kemampuan terapi suportif meningkat $83.33 \%$.

\section{PEMBAHASAN}

Hasil pengkajian menunjukkan bahwa klien risiko perilaku kekerasan sebagian besar berjenis kelamin laki-laki. Hasil pengkajian ini sesuai dengan hasil penelitian Wahyuningsih, Keliat, \& Hastono (2009), Gowi, Hamid, \& Nuraini (2011), dan Hidayati, Mustikasari, \& Pujasari (2011). Penelitian menunjukkan bahwa perilaku kekerasan lebih sering dilakukan oleh klien skizofrenia berjenis kelamin laki-laki.

Usia klien paling banyak adalah usia dewasa (25-56 tahun) sedangkan rata-rata usia klien adalah 34 tahun. Stuart (2013) menyatakan usia merupakan aspek sosial budaya yang menyebabkan terjadinya gangguan jiwa dengan risiko frekuensi tertinggi pada usia 2544 tahun. Mancuso et al (2010) mengungkapkan usia klien mempunyai hubungan dengan pengetahuan klien tentang penyakit.

Tingkat pendidikan klien risiko perilaku kekerasan yang dikelola paling banyak adalah SMP dan SMA. Stuart (2013) menyatakan tingkat pendidikan yang lebih tinggi ditemukan lebih sering menggunakan pelayanan 
kesehatan jiwa. Klien yang berpendidikan tinggi akan dapat membedakan antara kebutuhan dan keinginan.

Hasil pengkajian menunjukkan bahwa sebagian besar klien adalah tidak bekerja. Penelitian yang dilakukan oleh Sudiatmika, Keliat, \& Wardani (2011) bahwa klien yang mengalami skizophrenia ditemukan lebih banyak pada klien yang tidak bekerja dan hasil penelitian Lelono, Keliat, \& Bestral (2011) ditemukan bahwa klien skizofrenia banyak ditemukan pada klien yang tidak bekerja.

Sebagian besar klien belum menikah. Hidayati, Mustikasari, dan Pujasari (2011) dalam penelitiannya menunjukkan bahwa klien skizofrenia lebih banyak dialami klien yang belum menikah. Klien berada pada rentang usia dewasa, dimana klien mempunyai tugas perkembangan untuk mengembangkan hubungan intim dengan lawan jenis dalam ikatan pernikahan. Tidak terpenuhinya tugas perkembangan pada usia dewasa ini merupakan stressor bagi individu.

Lama sakit klien rata-rata 5 tahun, lama sakit paling pendek 1 tahun dan paling panjang 12 tahun. Kondisi kronis ini diperberat dengan adanya stigma bagi klien dan adanya beban yang berat yang harus ditanggung oleh keluarga. Stuart dan Laraia (2005) menyatakan bahwa waktu atau lamanya terpapar stressor memberikan dampak terhadap kemampuan dan kemandirian klien.

Faktor presipitasi (stimulus fokal) atau alasan klien dirawat di rumah sakit adalah di rumah marah-marah. Alasan yang lain adalah mengancam orang lain, memukul orang lain, merusak alat rumah tangga, dan mengganggu lingkungan. Faktor predisposisi adalah biologis yaitu berhubungan dengan struktur dan fungsi otak serta neurotransmiter, selain dapat dipengaruhi pula oleh faktor genetik. Menurut Townsend (2005), terjadinya gangguan perilaku dapat disebabkan oleh adanya kondisi patologis seperti tumor otak, stroke, dan infeksi otak. Selain itu juga disebabkan terjadinya ketidakseimbangan dari beberapa neurotransmiter misalnya dopamin, serotonin, norepineprin, dan lainnya.

Klien risiko perilaku kekerasan di ruang Dewi Amba banyak yang mempunyai kepribadian tertutup. Kepribadian tertutup ini disebabkan karena kegagalan dalam perkembangan.
Kegagalan tugas perkembangan menyebabkan kepribadian introvert, gangguan kemampuan komunikasi verbal, menutup diri dari orangorang yang memperhatikannya, dan tidak memiliki orang terdekat atau orang berarti.

Faktor sosio kultural yang paling banyak ditemukan adalah tidak bekerja atau tidak punya penghasilan. Status sosial ekonomi yang rendah lebih rentan terhadap terjadinya gangguan jiwa dibandingkan dengan status sosial ekonomi tinggi (Towsend, 2014). Penilaian terhadap stressor sudah sesuai dengan penelitian sebelumnya. Sudiatmika, Keliat, \& Wardani (2011), Volavka (2012) menemukan bahwa klien risiko perilaku kekerasan menunjukkan tanda dan gejala tidak mampu mengontrol perilaku kekerasan, mempunyai pikiran negatif dalam menghadapi stressor, mendominasi pembicaraan, sarkasme, meremehkan keputusan, fight of idea, perubahan isi pikir, ingin memukul orang lain, dan menyalahkan orang lain. Stuart (2013) menyatakan bahwa respon afektif klien perilaku kekerasan adalah perasaan tidak nyaman, merasa tidak berdaya, jengkel, merasa ingin berkelahi, mengamuk, bermusuhan, sakit hati, menyalahkan, menuntut, mudah tersinggung, euporia yang berlebihan atau tidak tepat, dan afek labil.

Stuart (2013) menyatakan bahwa perilaku kekerasan dapat dilihat dari wajah tegang, tidak bisa diam, mengepalkan tangan, rahang mengencang, peningkatan pernafasan, dankadang-kadang kataton. Perilaku yang ditunjukkan pada klien resiko perilaku kekerasan adalah mondar-mandir, tidak mampu untuk duduk tenang, tangan mengepal, menghentikan aktivitas motorik dengan tibatiba, kata-kata menekan, suara keras, memerintah (Stuart, 2013). Stuart (2013) juga menyatakan bahwa ancaman yang ditujukan pada obyek nyata atau imajiner menimbulkan gangguan seperti menarik perhatian, suara keras, dan kata-kata menekan. Respons yang ditemukan pada klien sudah sesuai dengan teori yang ada.

Sumber koping yang dimiliki klien adalah klien mengungkapkan bahwa cara yang dilakukan ketika emosi mengucapkan istighfar. Kemampuan lain yang dimiliki klien adalah mampu mengenal marah dan mengotrol emosi dengan fisik yaitu tarik nafas dalam dan pukul bantal. Klien mengungkapkan bahwa setiap kali marah klien melakukan tarik nafas 
dalam sambil mengucapkan istighfar. Kemampuan mengucapkan secara verbal dan patuh minum obat. Kepatuhan minum obat merupakan kemampuan yang paling kecil karena klien merasa sudah sembuh, ada perasaan bosan, dan takut adanya efek samping jika minum obat dalam jangka waktu lama. Klien yang sudah pernah dirawat di rumah sakit sudah pernah dilatih bagaimana cara untuk mengontrol emosi dan klien mampu mengungkapkan cara mengontrol emosi dibandingkan dengan yang baru pertama kali dirawat. Semakin banyak latihan yang diberikan kepada klien diharapkan semakin besar kapasitas kemampuan yang dimiliki klien. Diharapkan klien mampu mengantisipasi dan mengatasi stressor yang ada.

Mekanisme koping yang digunakan klien adalah denial yaitu pernyataan tidak setuju terhadap realitas dengan mengingkari terhadap realitas tersebut. Klien menyangkal kenyataan dengan menolak pengalaman yang tidak menyenangkan unuk melindungi dirinya (Stuart, 2013). Klien perlu dilatih untuk menggunakan koping adaptif yang baru dengan pemberian assertiveness training dan terapi kelompok suportif pada klien resiko perilaku kekerasan. Assertiveness training dan terapi kelompok suportif diberikan untuk melatih klien belajar ketrampilan baru untuk beradaptasi terhadap stimulus yang ada.

Regulator yang digunakan klien adalah reaksi tubuh saat mengalami putus obat yaitu klien sulit tidur, merasa gelisah, mudah tersinggung. Cognator yang dialami klien adalah klien menganggap minum obat itu membosankan, minum obat mempunyai banyak efek samping, klien merasa sudah sembuh, merasa sudah enak, sudah tidak marah-marah lagi, dan sudah bisa tidur. Keadaan ini menimbulkan klien kambuh lagi.

Pemberian asertiveness training dan terapi kelompok suportif pada klien resiko perilaku kekerasan sesuai dengan konsep model adaptasi Roy. Konsep model adaptasi Roy diarahkan pada konsep input, proses kontrol, efektor dan output. Intervensi assertiveness training dan terapi kelompok suportif diberikan untuk meningkatkan mekanisme koping pada klien resiko perilaku kekerasan dalam menyelesaikan masalahnya.
Kedua pendekatan terapi spesialis yang diberikan yaitu assertiveness training dan kombinasi assertiveness training dengan terapi kelompok suportif sama-sama berpengaruh terhadap penurunan tanda dan gejala resiko perilaku kekerasan, namun terdapat perbedaan penurunan tanda dan gejala. Pemberian assertiveness training dengan terapi kelompok suportif lebih bermanfaat dalam menurunkan tanda dan gejala risiko perilaku kekerasan dibandingkan dengan pemberian assertiveness training saja. Perbedaan ini dapat dilihat dari selisih penurunan tanda dan gejala yaitu sebesar $14.30 \%$.

\section{SIMPULAN}

Pelaksanaan assertiveness training dan terapi kelompok suportif menggunakan pendekatan Teori Stres Adaptasi Stuart dan Adaptasi Roy membantu dalam memberikan asuhan keperawatan spesialis, mulai dari pengkajian, penetapan diagnosis keperawatan, penetapan tujuan, penyusunan intervensi keperawatan, implementasi, dan evaluasi. Penggunaan Teori Stres Adaptasi Stuart dan Adaptasi Roy ini sangat tepat digunakan untuk menjabarkan asuhan keperawatan pada klien risiko perilaku kekerasan.

\section{DAFTAR PUSTAKA}

Aini, K., Keliat, B.A., dan Nuraini, T., 2011. Pengaruh assertive training therapy terhadap kemampuan asertif suami dan risiko kekerasan dalam rumah tangga di Bogor. Tesis FIK UI. Tidak dipublikasikan.

BuckleyL.A., Petitt,T.A.C.L., Adams, C.E., 2010. Supportive therapy for schizophrenia. http://www.thecochranelibrary.com

Degleris dkk., 2008. Assertivenessss training is a major component element of a psycoeducational program addressed to psychiatric patients and their families. BioMedCentral. http://www.annals.general.

Gowi, A., Hamid, A.Y.S., dan Nuraini, T., 2011. Pengaruh latihan asertif terhadap perilaku kekerasan orang tua pada anak usia sekolah di Kelurahan Tanjungpura kabupaten Karawang. Tesis UI. Tidak dipublikasikan. 
Hidayati, E., Mustikasari, dan Pujasari, H., 2011. Pengaruh terapi kelompok suportif terhadap kemampuan mengatasi perilaku kekerasan pada klien skizofrenia Di Rumah Sakit Jiwa Dr. Amino Gondohutomo Kota Semarang. Tesis. Tidak dipublikasikan.

Kaplan dan Sadock, 2010. Buku ajar psikiatri klinis. Edisi 2. Jakarta: EGC.

Klinberg, S., Jacobi, U.E., dan Wittorf, A., 2010. Supportive therapy for schizophrenic disorders. Germany: Univerity of Tubingen. www.carger.com

Lelono, S. K., Keliat, B.A., dan Besral., 2011. Efektivitas Cognitive Behavioral Therapy (CBT) dan Rational Emotive Behavioral Therapy (REBT) terhadap klien perilaku kekerasan, halusinasi dan harga diri rendah Di $R S \quad D r . H$. Marzoeki Mahdi Bogor. Tesis. Tidak Dipublikasikan

Lin dkk., 2008. Evaluation of assertiveness training for psychiatric patients. Journal of Clinical Nursing. 17. 2875-2883.

Mohr,W.K., 2006. Psychiatric mental health nursing. (6 th ed). Philadelphia. Lippincott Williams \& Wilkins.

Sledge, W.H., 2011. Effectiveness of peer support in reducing readmissions of persons with multiple psychiatric hospitalization. Psychiatric Services. ps.psychiatryonline.org. May,2011. Vol 62 No 5. P. 541-544.

Stuart, G. W., 2013. Principles and Practice of Psychiatric Nursing (9 ed.). Missouri: Mosby, Inc.

Sudiatmika, I.K. Keliat, B.A., dan Wardani, I.Y., 2011. Efektivitas Cognitive Behavioral Therapy $(C B T)$ dan Rational Emotive Behavioral Therapy (REBT) terhadap klien dengan perilaku kekerasan dan halusinasi Di RS Dr. H. Marzoeki Mahdi Bogor. Tesis. Tidak Dipublikasikan.

Undang-Undang Nomor 36 Tahun 2009 Tentang Kesehatan.
Townsend, M.C., 2014. Essentials of Psychiatric Mental Health Nursing Concepts of care in Evidence-Based Practice. Eighth Edition. Philadelphia, F.A. Davis Company.

Wahyuningsih, D., Keliat, B.A., dan Hastono, S.P., 2009. Pengaruh Assertiveness Training Terhadap Perilaku Kekerasan pada Klien Skizofrenia. (Tesis). Depok. Tidak dipublikasikan

Videbeck, 2008. Buku ajar keperawatan jiwa. Jakarta: EGC. 